Abstracta Iranica Abstracta Iranica

Revue bibliographique pour le domaine irano-aryen

Volume 32-33 | 2013

Comptes rendus des publications de 2009-2010

\title{
Lloyd Ridgeon. Morals and Mysticism in Persian Sufism: A History of Sufi-Futuwwat in Iran
}

Ève Feuillebois-Piérunek

\section{(2) OpenEdition \\ 12 Journals}

Édition électronique

URL : http://journals.openedition.org/abstractairanica/40322

DOI : 10.4000/abstractairanica.40322

ISSN : 1961-960X

\section{Éditeur :}

CNRS (UMR 7528 Mondes iraniens et indiens), Éditions de l'IFRI

\section{Édition imprimée}

Date de publication : 1 décembre 2013

ISSN : 0240-8910

\section{Référence électronique}

Ėve Feuillebois-Piérunek, « Lloyd Ridgeon. Morals and Mysticism in Persian Sufism: A History of SufiFutuwwat in Iran », Abstracta Iranica [En ligne], Volume 32-33 | 2013, document 377, mis en ligne le 01 juillet 2016, consulté le 26 septembre 2020. URL : http://journals.openedition.org/abstractairanica/ 40322 ; DOI : https://doi.org/10.4000/abstractairanica.40322

Ce document a été généré automatiquement le 26 septembre 2020.

Tous droits réservés 


\title{
Lloyd Ridgeon. Morals and Mysticism in Persian Sufism: A History of Sufi-Futuwwat in Iran
}

\author{
Ève Feuillebois-Piérunek
}

\section{RÉFÉRENCE}

Lloyd Ridgeon. Morals and Mysticism in Persian Sufism: A History of Sufi-Futuwwat in Iran. London, Routledge, 2010, $240 \mathrm{p}$.

1 L'ouvrage est consacré à la notion de "chevalerie" (javānmardī) dans la tradition persane soufie. Il s'appuie sur un travail de terrain en Iran et une analyse de sources en arabe et en persan pour dessiner à grands traits l'histoire de la futuwwa persane. Il la présente comme une philosophie pratique plutôt qu'une métaphysique: c'est avant tout un code d'honneur, prescrivant loyauté, humilité, générosité et bravoure. Cependant, elle entretient des liens très étroits et durables avec le soufisme.

2 La dimension sociale est présente dès le début chez les 'ayyārān, dont les connections avec la Malāmatiyya sont certainement à explorer. Entre le $\mathrm{XI}^{\mathrm{e}}$ et le XIII ${ }^{\mathrm{e}}$ siècles, des auteurs soufis comme Sullamī, Haraqānī et Ibn 'Arabī discutent et spiritualisent ce concept qui devient peu à peu l'éthique des classes laborieuses. L'adoption et l'institutionnalisation de la futuwwa par le calife al-Nāṣir et Sohravardī lui font gagner en respectabilité. À la période timouride, les écrits de Vā‘ez Kāšefī révèlent les liens serrés tissés entre futuwwa, soufisme et bazar. L'A. examine ensuite la question des soufis qalandars de l'Iran safavide, la critique du concept au XIX ${ }^{\mathrm{e}}$ s. suite à l'avènement de la modernité et montre comment le zūrHāne illustre le déclin de la futuwwa, alors que le lien avec le soufisme se trouve remplacé par le nationalisme et le chiisme.

3 L'ouvrage semble un peu vite écrit, avec une introduction trop rapide, l'absence de conclusion, et des transitions parfois insuffisantes entre les chapitres, et donc les différentes mouvances ou moments de la futuwwa. L'A. le reconnaît d'ailleurs bien 
volontiers, et s'en excuse, invoquant des contraintes temporelles et des impératifs de format. Il n'en demeure pas moins que ce livre, pourvu d'une bibliographie et d'un index, est le premier ouvrage en anglais consacré à cette thématique et qu'il s'avère très éclairant sur le sujet.

\section{AUTEURS}

\section{ÈVE FEUILLEBOIS-PIÉRUNEK}

Université Sorbonne Nouvelle-Paris 3, Mondes iranien et indien, Paris 